Prace Komisji Geografii Komunikacji PTG Transport Geography Papers of Polsh

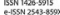
$21(4) / 2018$

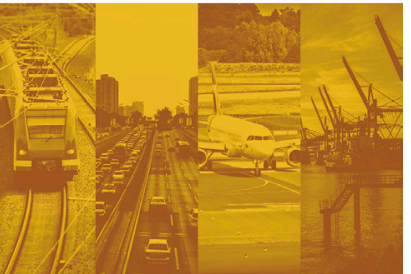
Transport Geography Papers of Polish Geographical Society

$2018,21(4), 14-19$

DOI 10.4467/2543859XPKG.18.021.10779
Received: 10.10.2018

Received in revised form: 09.12.2018

Accepted: 21.12 .2018

Published: 29.12.2018

\title{
NATIONAL AND INTERNATIONAL PASSENGER TRANSPORT ACCESSIBILITY OF THE KALININGRAD REGION OF THE RUSSIAN FEDERATION: PRESENT CONFIGURATION AND DEVELOPMENT PLANS
}

\author{
Krajowa i międzynarodowa dostępność transportu pasażerskiego w Obwodzie \\ Kaliningradzkim Federacji Rosyjskiej: współczesna konfiguracja i plany rozwoju
}

\section{Ivan S. Gumenyuk}

Department of Geography, Nature Management and Spatial Development, Institute of Environmental Management, Urban Development and Spatial Planning, Immanuel Kant Baltic Federal University, Zoologicheskaya 2, 236022, Kaliningrad, Russia

E-mail: IGumeniuk@kantiana.ru

\section{Citation:}

Gumenyuk I.S., 2018, National and international passenger transport accessibility of the Kaliningrad region of the Russian Federation: present configuration and development plans, Prace Komisji Geografii Komunikacji PTG, 21(4), 14-19.

\begin{abstract}
The article is devoted to the description of the current level of development of passenger transport system of the Kaliningrad region of the Russian Federation. First of all, the possibilities of providing passenger traffic in international and intra-national (between regions of Russia) directions are assessed. Each of the types of transport in the region, which is involved in the provision of passenger services, is characterized. The information base of the study consists of statistical and analytical materials on the work of passenger transportation for 2016 and 2017. The main research method is the method of statistical comparison and expert analysis. The main conclusion of the study is that at present there is asymmetry in the role of various types of transport involved in providing passenger traffic between the Kaliningrad region of the main territories of Russia and foreign countries. In addition, a list of promising projects that can be implemented to intensify the Russian-Polish passenger traffic. It is necessary to implement new projects in the formation of passenger corridors, which will be aimed at expanding the possibilities of transport communication. The availability of alternative routes in a competitive environment leads to both an increase in the quality of transportation services provided and a reduction in their cost to the public.
\end{abstract}

Key words: Kaliningrad region, transport system, passenger transport 


\section{Introduction}

Kaliningrad region is a geographically unique region of Russia. Territorially divided from the main territory of Russia, the socio-economic processes of the region directly depend on the degree of connectivity with the mainland. The transport system of the Kaliningrad region performs the functions of providing these links. The nature and level of development of both the region itself and the degree of integration of the Kaliningrad region into the national and international space depend on the degree of its development. In the context of effective socio-economic development of the region, the efficiency of the region's transport links with the main territory of Russia (national links) and foreign countries (international links) is crucial.

The development of the transport and logistics complex of the Kaliningrad region in the context of integration processes has been actively developed since the mid-2000s, when the integration processes covered both the economic and social spheres of life in the region. As applied to the transport and logistics complex, the issues of integration interaction within certain types of transport (for example, the port complex (Alekseeva, 2012; Meyler \& others, 2013), railway transport (Adamov \& Protasova, 2014), and complex as a whole (Gumenyuk \& Orlov, 2014; Gumeniuk, 2013). The problems of transport communication between the border regions of Russia and Poland, as a basic element of ensuring developing cross-border connections between neighboring territories, were particularly actively studied (Anisiewicz \& Palmowski, 2014; Studzinska \& Rzyski, 2015). At the same time, the problem of ensuring and ways of increasing the region's transport connectivity from the main territory of Russia and the development of the region's transport and logistics complex in the context of Eurasian integration are not so actively studied in the academic environment. Separate publications on these issues are just beginning to appear (Druzhinin \& Dong, 2018). However, to a greater extent, researchers are considering the function of providing freight traffic, while the problems of passenger traffic remain outside the field of vision of researchers. At the same time, it is the function of stable passenger traffic primarily between the Kaliningrad region and the main territories of Russia that is the most important social task of the region's transport complex.

\section{Research methodology}

The research methodology is based on analytical and statistical assessment of the role of certain modes of transport, in providing national and international passenger traffic. Also on the basis of expert analysis, key problems are formulated and further trends in the development of each of the presented modes of transport are projected. Separately, present transport corridors of the Russian-Polish passenger communication are analyzed separately, and design solutions for the development of transport communication between the Kaliningrad region of the Russian Federation and the border voivodships of the Republic of Poland are formulated.

\section{Present characteristics of the passenger transport complex of the Kaliningrad region}

From the point of view of performing the function of providing passenger traffic, the elements of the transport system are involved in different ways. In the provision of passenger communication from the main territories of Russia three types of transport are involved: aviation, automobile and railway, and only two are participating in the provision of international passenger traffic: aviation and automobile (Table 1).

Table 1. The role of various modes of transport in providing passenger connections of the Kaliningrad region from the main territories of the Russian Federation and foreign countries

\begin{tabular}{ccc} 
Type of transport & Kaliningrad region - Russia & Kaliningrad region - foreign countries \\
\hline Aviation & + & + \\
Automobile & + & + \\
Railway & + & - (with the exception of Belarus and Lithuania) \\
Maritime & - & - \\
$\begin{array}{c}\text { Inland waterways (including } \\
\text { coastal shipping) }\end{array}$ & - & - \\
\hline
\end{tabular}

Source: Created by the author. 
Various elements of the transport infrastructure of the Kaliningrad region are involved in providing interregional and international passenger traffic. The air traffic is provided by the only «Khrabrovo» international airport in the region, located $17 \mathrm{~km}$ northeast of Kaliningrad. This airport, in preparation for the World Cup in Russia in 2018, underwent significant modernization, as a result of which it extended and strengthened the runway, as well as reconstructed the airport terminal complex. Due to this, the estimated airport capacity increased to 2 thousand passengers per hour (5 million passengers per year, instead of 1.1-1.2 million passengers before reconstruction).

Railway passenger traffic is currently provided by only one checkpoint in the village Chernyshevskoe (on the Russian-Lithuanian border). In total, there are five railway checkpoints on the territory of the Kaliningrad region, but passenger service is carried out only through one of them.

Maritime transport and the port complex of the region currently does not practically participate in passenger traffic. Despite the fact that there are ferry services between the Kaliningrad region and the main territory of Russia, the ferries that run along this route specialize in cargo transportation. In 2015-2017, the total number of passengers using the ferry service was only 5 thousand people, while to a large extent these were persons performing the cargo escort function.

Automobile transport, in terms of infrastructure facilities used, is the most territorially diverse. All automobile checkpoints operating in the Kaliningrad of Russia is expertly estimated at 2 million people (Table 2). The leader is aviation transport $-75 \%$ of the total volume of transported passengers, rail and automobile have comparable indicators. For comparison 15 years ago (in 2001) the leader was the railway transport (more than 900 thousand passengers), and the aviation and automobile had a comparable volume of transported passengers (at the level of 220-230 thousand people).

Passenger traffic between the Kaliningrad region and foreign countries is currently mainly provided by air and road transport (personal vehicles and bus network). Expert assessments (in the absence of official statistics) determine the volume of international passenger traffic to and from the Kaliningrad region at the level of 2 million people per year (excluding cross-border movement and transit to the Russian Federation through the territory of third countries). Thus, the total passenger traffic volume of the Kaliningrad region with the main territory of Russia and foreign countries is estimated at 4 million people per year.

Increase the mobility of the inhabitants of the region, development of the Kaliningrad region as a tourist (Studzieniecki, Palmowski \& Korneevets, 2017), business and economic center and the growing need to export labor resources from other regions of the Russian Federation or foreign countries allows us to predict further growth in passenger traffic. In such conditions, the passenger communication system of the region needs significant infrastructure, organizational, institutional modernization.

Table 2. The volume of passenger traffic between the Kaliningrad region and the main territory of Russia following the results of 2016 (in the context of certain modes of transport)

Type of transport

$\begin{array}{cc}\text { Aviation } & 1570 \\ \text { Railway } & 256 \\ \text { Automobile } & 220 \\ \text { TOTAL: } & 2046\end{array}$

Source: Created by the author.

Region (4 on the Russian-Polish border and 4 on the Russian-Lithuanian border) provide both passenger and freight traffic. The Mamonovo II-Grzechotki automobile checkpoint has the highest capacity (about 6.5 thousand cars per day), which is currently the last in time to open in the region (opened in 2010).

By the end of 2016, the total volume of passenger traffic between the region and the main territory

\section{Description}

We will describe the current problems of passenger traffic that exist for key types of transport and which solutions are offered or are already being implemented in the Kaliningrad region.

Aviation transport is the key mode of transport in the service of external passenger traffic in the Ka- 
liningrad region. Together with the infrastructure restrictions of the only civilian airport in the region - Khrabrovo, which are largely solved during the preparations for the 2018 World Cup, it is still possible to note the actual problem, namely the small number of regular routes. The airport schedule for the summer of 2018 notes that the region has 19 regular routes: 10 international and 9 national routes. For the Kaliningrad region, given its socio-economic characteristics and location, such a number of regular routes is not sufficient. For comparison, the airport of Poznan (Poland), with a population comparable to Kaliningrad, has 29 regular routes. The airport of Dortmund (Germany) (also comparable in population to Kaliningrad) has 37 regular routes. By the number of passengers carried by the end of 2016, all three airports are similar: Kaliningrad - 1 570.8, Poznan 1 295.6, Dortmund - 1920.0 thousand passengers. Kaliningrad has the prerequisites to become an aviation transport hub that could connect the major Russian cities, as well as the cities of the countries-members of the Eurasian Economic Community (primarily Kazakhstan, Uzbekistan, Armenia) to the cities of the Baltic region. Now these opportunities are not being realized, passengers are forced to use the Moscow and St. Petersburg aviation hubs for transfer, as well as to rely on the Gdansk, Warsaw and Riga air hubs.

Prospects for the development of air transport are seen in the reorganization of the Khrabrovo airport operation model with the aim of creating a subregional air hub on its basis. The airline "KD Avia", which functioned until 2009, proved in practice the possibility of the Kaliningrad air hub operating under such a model. Simultaneously with the new form of the organizational model, the creation of a regional air carrier on the principles of public-private partnership, in which one of the co-sponsors would be the Government of the Kaliningrad region, looks promising. This will allow the regional government to regulate pricing in the air transportation market, and also participate in the development of the airport's route network based on the priorities of the region's development.

Railway transport in recent years has lost its leading position in the passenger transportation sector between the Kaliningrad region and the main territory of the country, and is not currently involved in providing international passenger traffic. The entire inter-regional passenger traffic is formed on the routes Kaliningrad-Moscow and Kaliningrad-St. Petersburg. Reducing the number of passengers carried by rail is associated with a number of problems:

- large temporary losses for passengers (the Moscow-Kaliningrad train is 22 hours, the KaliningradSt. Petersburg train is 23 hours);
- discomfort when crossing state borders (border and customs clearance takes place at night, which is inconvenient for passengers);

- the need to issue a special travel document FRTD, not later than a day before departure, and only one you has a passport and is personally present in the ticket office of the station.

The main direction of improvement of the railway passenger communication in the region is the optimization of the mode of movement of existing routes. Negotiations between the administrations of the railways of Russia, Lithuania and Poland, as well as the relevant border services on the passage of border controls during the movement of the train across the territory of the respective state, will already be blown out. Their successful completion will allow in the future to reduce the time of the train (it is planned that a train from Kaliningrad to Moscow will be able to reach in 14 hours) and to eliminate the need for passage of night border control. Under such conditions and the competent formation of a train schedule, it is possible to assess the long-term prospects of a longdistance passenger rail service in the region. Another promising area for the development of passenger rail services in the region is the organization of new passenger routes, primarily connecting the region with foreign countries (Poland, Germany). In this context, it seems advisable to implement a project to launch a railway communication on the route St. Petersburg - Latvia - Lithuania - Kaliningrad - Poland - Berlin, which will expand the channels of passenger traffic between the region and foreign countries.

Road transport plays an important role in providing passenger connections, both internationally and nationally. The development of passenger transport by road is currently limited to the capacity of the sections of the state border between the region and neighboring countries. On the Russian-Lithuanian section there are 4 automobile checkpoints with a total throughput of 3900 vehicles a day. On the Russian-Polish state border, there are also 4 automobile checkpoints with an aggregate throughput of 6,700 vehicles per day.

The prospects for the development of automobile passenger transport on the one hand are related to the improvement of the work of border and customs services in order to accelerate their work, for example, through the introduction of mechanisms for a "green corridor", "preliminary electronic declaration", etc. And in this regard, it is important to continue and further intensify work in the format of sectoral international councils or working groups, for example, such as the Russian-Polish working group on customs matters, established within the framework of the current international of Russian-Polish 
cooperation of customs services. On the other hand, the infrastructure development of the network of checkpoints is of no small importance. In this regard, it is important to note that in the near future a new automobile checkpoint will be put into operation on the Sovietsk-Dubki Russian-Lithuanian border with a design capacity of 4,000 vehicles per day.

Sea transport in the region was in a unique situation. In the coastal Kaliningrad region, where sea and water transport plays a key role in the cargo specialization of the region, they practically do not participate in providing passenger communications. Organizational, infrastructural and institutional actions are being taken in the region to eliminate this problem, the main one of which is the construction of an international sea terminal for the reception of cruise and cargo-passenger vessels in the resort town of Pionersky. The project, which is scheduled to be completed in 2020, will allow reception of cruise ships and ferries in the region. Not only will a specialized marine infrastructure be created, the project implies the construction of a passenger terminal capable of carrying out border and customs screening of passengers, as well as ensuring the reception of ferries capable of carrying rolling goods. The appearance of the Kaliningrad region on the cruise map of the Baltic Sea opens the prospects for the integration of the region into the existing cruise routes developed in the Baltic region. It is planned that the new port will be able to provide up to 110 ships per year, with a total passenger volume in the region of 225 thousand people. At the same time, the new marine terminal will provide a new infrastructure base for ferry services. Regional authorities plan that the ferry complex will be able to provide up to 200 ships per year, with a total volume of transported passengers of at least 70 thousand people per year. First of all, the active development of the Kaliningrad-Ust-Luga ferry line is planned, but at the same time there are plans for the development of international ferry routes, primarily with the nearest ports of Poland and Lithuania.

\section{Discussion}

Separately, it is advisable to dwell on the issue of passenger transportation between the Kaliningrad region and the border regions of the Republic of Poland. Modern passenger traffic between border regions is provided exclusively by road transport, although in certain periods of history it was also provided by water and rail transport (Rozhkov-Jur'evskij, 2015; Anisiewicz \& Palmowski, 2016; Mironyuk \& Żęgota, 2017). At the present stage of the Polish-Russian cross-border cooperation, various projects have been discussed and proposed that can significantly expand the pos- sibilities of passenger transport communication between the border regions:

1. In the field of road transport, there are projects that provide for the modernization of existing and construction of new automobile checkpoints on the Russian-Polish border. The latter is supposed to be built in the area of the village Krylovo, near the city of Bagrationovsk.

2. In the field of inland waterway transport, there are several different projects designed to launch regular cargo and passenger traffic along the Kaliningrad / Vistula Gulf.

3. In the maritime sector we are talking about the already mentioned project of launching a cruise and ferry service using the international port of Pionersky, capable of providing the formation of cruise and ferry regular routes between the Polish seaside towns and the Kaliningrad region.

4. In the field of inland waterway transport, the project of launching cargo and passenger navigation on the Masurian Canal is also being discussed, although this project is more promising in the context of the development of cross-border tourist water and water-land routes (Studzieniecki, Palmowski \& Korneevets, 2016)

5. There is a regular passenger rail service between Kaliningrad and Tricity on the railways. The test launch of this train took place in early 2018, received a generally positive approval from both the Polish and the Russian side.

6. There is also a project for a regular air service between Kaliningrad and Gdansk.

7. In the field of development of environmentally friendly alternative modes of transport, there is a project for the infrastructure development of bicycle routes in the Kaliningrad region, with a view to realizing the inclusion of the region in a network of European bicycle routes, actively developing on the territory of the border regions of the Republic of Poland.

The listed projects have different time horizons for their implementation, and also vary greatly in the amount of resources that will need to be invested in their implementation. High probability of realization in the short term is the water communication project using the sea terminal in Pionersky port, as well as the project of launching regular passenger rail service across the border, using a railway with European gauge.

\section{Conclusions}

Summing up, it is necessary to state the presence of asymmetry in the role of various modes of transport involved in providing passenger communication be- 
tween the Kaliningrad region of the main territories of Russia and foreign countries. It is necessary to implement new projects in the area of the formation of passenger corridors, which will be aimed at expanding the possibilities of transport communication. The availability of alternative routes, in a competitive environment, leads both to an increase in the quality of transport services provided and to a decrease in their cost to the population. Both the first and second will directly affect the competitiveness of the region at the national and international level.

\section{Acknowledgements}

This article has been prepared under project № 1817-00112 «Ensuring economic security of Russia's western border regions in the conditions of geopolitical turbulence» (grant from the Russian Science Foundation).

\section{References}

Adamov N. A., Protasova S.A., 2014, Legal risks and features of railway logistics in Kaliningrad, Legislation and economics, 3, 33-37.

Alekseeva L. A. 2012, The main problems and prospects of competitive development of the Kaliningrad sea transport complex // News of the Baltic State Academy of the Fishing Fleet: psychological and pedagogical sciences, 4 (22),172-176.

Anisiewicz R., Palmowski T., 2016, Cooperation of Poland and the Kaliningrad oblast of the Russian federation -An important factor of Baltic integration. Prace i Studia Geograficzne ,61(1),13-28.

Anisiewicz R., Palmowski, T. 2014, Small border traffic and cross-border tourism between Poland and the Kaliningrad oblast of the Russian Federation, Quaestiones Geographicae, 33 (2), 79-86.

Druzhinin A.G., Dong Y., 2018, One Belt - One Road initiative: A window of opportunity for Russia's western border regions, Baltic Region, 10 (2), 39-55.

Gumeniuk I., 2013, The INTERREG IIIB BSR Programme as a tool for developing a unified transport system in the Baltic macroregion, Baltic Rim Economies, 3, 72-73.
Gumenyuk I., 2015, The Current State and Prospects for the Development of the Transportation Industry of the Kaliningrad Oblast. Mediterranean Journal of Social Science, Vol 6, No 6 S7, DOI 10.5901/mjss.2015.v6n6s7p95

Gumenyuk I., Orlov S., 2014, The Kaliningrad region as a potential coastal transport cluster. Baltic region, 3 (21), 100-108. doi: 10.5922/2079-8555-2014-3-9

Meyler L., Moiseenko S., (eds), 2013. Methods and models to optimize functioning of transport and industrial cluster in the kaliningrad region. Marine Navigation and Safety of Sea Transportation: STCW, Maritime Education and Training (MET), Human Resources and Crew Manning, Maritime Policy, Logistics and Economic Matters, 225-232

Mironyuk D. A., Żęgota K., 2017, The History of the Integration between Russia's Kaliningrad Region and Poland's Northeastern Voivodeships: A Programme Approach. Balt. reg., 9(2), 114-129, doi: 10.5922/2079-8555-20172-9.

Rozhkov-Jur'evskij Ju. D., 2015, «On the history of RussianPolish interaction at the Kaliningrad / Vistula Lagoon» in G. M Fedorov, V. A Gritsenko (eds) Spatial Planning as a Tool for Coordinating the Development of Ports and Harbors of the Kaliningrad / Vistula Gulf [Prostranstvennoe planirovanie kak instrument koordinacii razvitija portov i gavanej Kaliningradskogo/Vislinskogo zaliva], Izd-vo BFU im. I. Kanta, 99-102.

Studzieniecki T., Palmowski T., Korneevets V., 2016, The system of cross-border tourism in the Polish-Russian borderland. Procedia Economics and Finance, 39, 545-552.

Studzieniecki T., Palmowski T., Korneevets V., 2017, The tourism accessibility of the Kaliningrad Region in Baltic Europe. Conference: XX. mezinárodní kolokvium o regionálních vědách. Sborník příspěvků, 77-779. DOI 10.5817/CZ.MUNI.P210-8587-2017-101

Studzińska D. B., Rzyski S. 2015, Border transformation and its impact on the region. Polish-Russian borderland after coming into force of the agreement of local border traffic [Transformacja granicy i jej oddziaływanie na region. Pogranicze polsko-rosyjskie po wejściu w zycie małego ruchu granicznego], Annales Universitatis Mariae Curie-Sklodowska. Sectio B, 70 (2), 179-190. 